\title{
Weight Management of Urban Educated Elderly for Healthy
}

\section{Ageing}

\section{Suresh $\mathrm{K}^{*}$}

Public Health Consultant, India

*Corresponding author: Suresh Kishanrao, Karnataka State Rural Development University, Public Health Consultant, India, Email: ksuresh.20@gmail.com

\section{Short Communication}

Volume 2 Issue 5

Received Date: October 14, 2019

Published Date: October 22, 2019

DOI: $10.23880 /$ jqhe- 16000140

\section{Abstract}

Background: UNICEF, India country office has seen hundreds of its staff retiring in last 15 years. The UNICEF retired staff Association has been organizing reunion for their members since 2015. These meetings were general get together and spending happy time together. Sightseeing, entertainment and organizational update including the benefits for the retired staff were the agenda. In their 2017 reunion in Bhubaneshwar, Odisha, the organizers had arranged a session on health challenges and management practices among retired colleagues. Retired health colleagues under the leadership of the author facilitated discussions and collated some useful management practices. Based on the individual or spouse's experiences of the best practices some guidelines were prepared and shared based to all. On the request of some of the colleagues in April 2018 a set of dietary advises series called "Awareness for Healthy Ageing of Senior-citizens And Selfempowerment (AHASAS) were prepared by this author and shared. One of the initial guidelines included suggestions to reduce the obesity that was shared to all 106 staff by this author after collating the data on overweight and obesity. A total of 23 Obese people based on their BMI out of 106 were identified and individual counselling regarding the dietary requirements of the senior citizen in terms of calories, proteins and fats along with exercise regimen, sleep improvement practices and a list of dietary items with their Glycaemic Index levels were collated and shared again.

Objective: To Assess if the Diet, exercise and sleep advises in general and inter-personal counselling on the willing overweight retired staff of an organization will be effective.

Keywords: Prevalence; Obesity; BMI; Hypertension; Diabetes; General Dietary Advice for Weight Management; Personal Counselling; Exercise Regimen and Sleep Counselling

\section{Introduction}

Weight that is higher than what is considered as a healthy weight for a given height is described as overweight or obese. Body Mass Index (BMI), is used as a screening tool for overweight or obesity. Body Mass Index (BMI) is a person's weight in kilograms divided by the square of height in meters. A high BMI can be an indicator of high body fatness. BMI does not measure body fat directly, but research has shown that BMI is moderately correlated with more direct measures of body fat. Overweight/obesity is defined by body mass index of more than $24.99 \mathrm{~kg} / \mathrm{m} 2$. Obesity results from the accumulation of excess fat on the body ${ }^{1}$. Obesity is considered a chronic (long-term) disease, like high blood pressure or diabetes. Obesity has many causes. Our age, 


\section{Journal of Quality in Health Care \& Economics}

gender, genes, psychological makeup, socioeconomic, and environmental factors all may contribute [1].

The distinctive features of obesity in Asian Indians include greater total, truncal, intra-abdominal and subcutaneous adipose tissue compared to white Caucasians. Fat deposition is seen in ectopic tissues like liver, pancreas, dorso-cervical region ('buffalo hump') and under the chin ('double chin') and this is closely associated with the metabolic syndrome [2]. The prevalence of obesity in India is increasing and ranges from $8 \%$ to $38 \%$ in rural and $13 \%$ to $50 \%$ in urban areas. Obesity is a risk factor for development of type 2 diabetes mellitus (T2DM), hypertension, dyslipidaemia, coronary heart disease and many cancers [3].

Between 1998 and 2016, overweight/obesity prevalence increased among men and women in both urban and rural areas [4]. In all periods, overweight/obesity prevalence was consistently highest among higher SEP individuals. In urban areas, overweight/obesity prevalence increased considerably over the study period among lower SEP adults. For instance, between 1998 and 2016, overweight/obesity prevalence increased from approximately 15\%-32\% among urban women with no education. Whereas the prevalence among urban men with higher education increased from $26 \%$ to $34 \%$ between 2005 and 2016, No notable changes were observed among high SEP urban women between 1998 and 2016. In rural areas, more similar increases in overweight/obesity prevalence were found among all individuals across the study period, irrespective of SEP. Among rural women with higher education, overweight/ obesity increased from $16 \%$ to 25\% between 1998 and 2016, while the prevalence among rural women with no education increased from $4 \%$ to $14 \%$ [5].

\section{Methods}

A cross sectional study was done among 106 retired UN organization's India office. The author had started a series of awareness creation efforts called "Awareness of Health of Ageing Senior Citizens AND Self-Empowerment (AHASAS) "by sharing knowledge to all 106 staff and providing personal advice on diet, exercises and sleep. In early 2018 a total of 23 candidates were identified as obese based on BMI in and were counselled online/over phone to moderate their diet, exercise and sleep practices and setting a target of reducing a weight of 30-50 G per day (10-15 Kg over a year). A follow up study of the BMI was done by this author in June 2019 (12-15 months of practicing the advises) to understand the impact of practices followed by the effected people. Baseline and recent measurements were taken by the staff themselves or their primary health care providers [6-12].

\section{Results}

There were 23 cases of obesity $\{6$-male $(26.1 \%) 17$ female (73.9\%)\}. Out of them 8 cases were with diabetes $(34.7 \%)$ and 16 cases were with Hypertension (69.1) in 2018. Among them 20 were able to reduce their weight from $3-10 \mathrm{Kg}$ in a span of 12-15 months of following dietary and exercise advises [13]. Two of the three did not continue in the study and one case did not achieve the weight reduction goals despite efforts, though she was able to reduce about $3 \mathrm{Kg}$ over a year. Five out of 8 diabetes cases reported a better Blood sugar maintenance and 12 of the Hypertensives reported better control of their hypertension.

\section{Conclusion}

General guidelines help obese persons to be aware and take steps to eat sensibly and maintain their normal weight and individual counselling empowers obese people to finetune their diet, exercise regimen and sleep practices to reduce the desired weight and manage their Diabetes and hypertension better.

\section{References}

1. Shannawaz M, Arokiasamy P (2018) Overweight/Obesity: An Emerging Epidemic in India. Journal of Clinical and Diagnostic Research 12(11): 15.

2. Behla S, Misraa A (2017) Management of obesity in adult Asian Indians. Indian Heart J 69(4): 539-544.

3. Gopalan C (1998) Obesity in The Indian Urban 'Middle Class'. NFI Bulletin 19(1): 1-4.

4. Ministry of Health \& Family Welfare.

5. Luhar S, Mallinson PAC, Clarke L, Kinra S (2018) Trends in the socioeconomic patterning of overweight/obesity in India: a repeated crosssectional study using nationally representative data. BMJ 8(10): 1-9.

6. (2018) India Today Web Desk. India.

7. Rao BB, Junapudi SS (2019) A comparative study of prevalence of overweight and obesity among urban 


\section{Journal of Quality in Health Care \& Economics}

and rural population of South India. IJCMPH 6(3): 1091-1095.

8. Suresh K (2019) AHASAS note. UNICEF.

9. Thomas S (2019) Best Indian Diet Plan for Weight Loss. Healthify Me.

10. Weight loss: The fool proof Ayurveda guide to lose weight in just 7 steps. India.
11. Gunnars K (2018) How to Lose Weight Fast: 3 Simple Steps, Based on Science. BSc Health Line.

12. Tighe JA (2013) The Freedom Diet. The Simple 6 Step System for Fast, Easy and Permanent Weight Loss.

13. Clinic M Weight loss: 6 strategies for success. 